\title{
Cryptococcus neoformans ISOLATION FROM SWALLOW (Hirundo rustica) EXCRETA IN IRAN
}

\author{
Mohammad T. HEDAYATI(1), Sabah MAYAHI(1), Mahdi FAKHAR(1), Tahereh SHOKOHI(1) \& Mohammad MAJIDI(1)
}

\begin{abstract}
SUMMARY
Cryptococcus neoformans is an encapsulated yeast that can cause cryptococcosis, a life-threatening infection that mainly occurs in immunocompromised patients. The major environmental sources of $C$. neoformans have been shown to be soil contaminated with avian droppings. In the present study, we evaluated the isolation of $C$. neoformans from swallow (Hirundo rustica) excreta in two northern cities of Iran. Ninety-seven swallow droppings were evaluated and 498 yeast-like colonies were isolated and identified as Rhodotorula spp. (62.8\%), Candida spp. (28.5\%) and C. neoformans (8.7\%). Cryptococcus neoformans was isolated from 5/97 (5.2\%) of collected samples. Min-Max colony forming units (CFU) per one gram for the positive samples were 3-10 C. neoformans colonies. The total mean CFU per one gram for the positive samples was 4.8. The results of this study demonstrate that excreta of swallow may harbor different species of potentially pathogenic yeasts, mainly $C$. neoformans, and may be capable of disseminating these fungi in the environment.
\end{abstract}

KEYWORDS: Swallow; Hirundo rustica; Excreta; Cryptococcus neoformans.

\section{INTRODUCTION}

Cryptococcus neoformans is an encapsulated yeast that causes cryptococcosis, a life-threatening infection that is usually manifested as meningoencephalitis mainly in immunocompromised patients $s^{3,8,9,16}$. The genus Cryptococcus includes nearly 90 species but the taxonomy of the genus is currently being re-evaluated. Among these, C. neoformans and C. gattii are pathogenic. Following its first identification in nature from peach juice samples ${ }^{24}$, the major environmental sources of $C$. neoformans have been shown to be either soil contaminated with avian droppings $(C$. neoformans) or eucalyptus trees and decaying wood forming hollows in living trees $(C \text {. gattii })^{4,11,12,26}$.

Cryptococcus neoformans can be divided in four serotypes (A to D). Until recently, serotypes A and D were included in var. neoformans, while serotypes B and $\mathrm{C}$ were included in C. gattii. However, in addition to the previously observed phenotypic differences, recent molecular studies have detected significant genetic variations between the two serotypes. Thus, it was proposed that a new variety, var. grubii, be created to contain serotype $\mathrm{A}^{5}$. This leaves serotype $\mathrm{D}$ as the sole serotype in var. neoformans.

Swallows are passerine birds in the family Hirundinidae which are characterized by their adaptation to aerial feeding. The family contains around 83 species in 19 genera. Hirundo rustica (barn swallow) is the most widespread species of swallow in the world. A distinctive passerine bird with blue upperparts, a long, deeply forked tail and curved, pointed wings, it is found in Europe, Asia, Africa and the Americas. There are six subspecies of Hirundo rustica, which breed across the Northern Hemisphere. Four are strongly migratory. Hirundo rustica is the type of swallow which migrates to northern Iran in spring season. Swallows have readily adapted to nesting in and around human habitation. They often return to the same breeding area each year, and may select the same nest site if they were previously successful in that location ${ }^{8}$. On the other hand, they are considered as a holy bird in the north and some other regions of Iran. Because of the high prevalence of swallows around human habitation, and the seriousness of cryptococcosis in humans, there is an interest in the relationship between the birds, their excreta, and human cryptococcosis. In addition, some investigators from Iran have suggested that the number of cryptococcosis cases is increasing ${ }^{1,18,23,27}$. Therefore, in the present study we evaluated the isolation of $C$. neoformans from swallow excreta in Sari and Qaemshahr, two northern cities of Iran.

\section{MATERIAL AND METHODS}

Study area. Sari, the capital of Mazandaran province is located in the north of Iran, between the northern slopes of the Alborz Mountains and southern coast of the Caspian (Mazandaran) Sea. Its population is estimated to be 250,000 . It has a land area of 3,923 square kilometers. Sari is one of the entertainment and sports centers of Iran. Qaemshahr, another city of Mazandaran province is situated 23 kilometers southwest of Sari. Its population is estimated to be 180,000 .

(1) Department of Medical Mycology and Parasitology, School of Medicine, Mazandaran University of Medical Sciences, Sari, Iran.

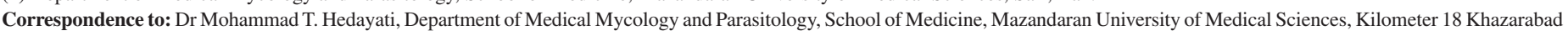
Road, P.O. Box 48175-1665, Sari, Iran. Tell: 0098-151-3543088. Fax: 0098-151-3543087. E-mail: hedayaty2001@yahoo.co.uk 
HEDAYATI, M.T.; MAYAHI, S.; FAKHAR, M.; SHOKOHI, T. \& MAJIDI, M. - Cryptococcus neoformans isolation from swallow (Hirundo rustica) excreta in Iran. Rev. Inst. Med. Trop. Sao Paulo, 53(3): 125-7, 2011.

During spring 2010, ninety-seven swallow desiccated droppings samples were collected from the two cities including two general hospitals and human dwellings.

Isolation and identification of Cryptococcus spp. The collected droppings were processed in a biohazard safety hood (Class II), each sample was ground into powder by a mortar with a porcelain pestle and then $1 \mathrm{~g}$ was suspended in $50 \mathrm{~mL}$ of sterile physiological saline $(0.9 \%$ aqueous $\mathrm{NaCl})$ containing $0.4 \mathrm{~g} / \mathrm{L}$ chloramphenicol, vigorously vortexed for 1-3 min and let stand for 15-20 min for decantation. Supernatants were removed by micropipettes and 10, 100, 200, and $500 \mu \mathrm{L}$ aliquots were seeded on Sabouraud dextrose agar plates with chloramphenicol $(0.05 \mathrm{mg} / \mathrm{mL})$, incubated for two to $15 \mathrm{~d}$ at $30^{\circ} \mathrm{C}$, and assessed daily. The grown yeast-like colonies were sub-cultured onto corn meal agar + tween 80 and CHROMagar media (HiMediaIndia) and they also assessed for phenoloxidase activity on Niger seed agar (Guizotia abyssinica (niger seed) $50 \mathrm{~g}$, dextrose $1 \mathrm{~g}$, KH2PO4 (potassium dihydrogen orthophosphate) $1 \mathrm{~g}$, creatinine $1 \mathrm{~g}$, agar 15 $\mathrm{g}$, Chloramphenicol $1 \mathrm{~g}$, Distilled water $1000 \mathrm{~mL}$ ) for $72 \mathrm{~h}$ at 30 ${ }^{\circ} \mathrm{C}$ and subjected to complementary tests as urease production on Christensen Urea Agar and ability to grow at $37{ }^{\circ} \mathrm{C}$. Cryptococcus neoformans variety was determined by growth and change of color in the canavanine-glycine-bromothymol blue medium.

\section{RESULTS}

Out of 97 collected samples, 498 yeast-like colonies were isolated. The isolated yeast-like colonies were identified as Rhodotorula $(62.8 \%)$, Candida spp. (28.5\%) and C. neoformans (8.7\%). Cryptococcus neoformans was isolated from 5/97 (5.2\%) of collected samples. Of five positive samples, two samples were collected from around the Qaemshahr General Hospital. None of the collected samples from Sari were positive for $C$. neoformans growth. Table 1 shows the number of isolated $C$. neoformans colonies based on sampling places. Min-Max CFU per one gram for the positive samples was 3-10 C. neoformans colonies. The total mean CFU per one gram for the positive samples was 4.8.

Table 1

Number of isolated $C$. neoformans colonies based on sampling places

\begin{tabular}{llc}
\hline Sample code & Sampling place & $\begin{array}{c}\text { Number of isolated } \\
\text { colonies }\end{array}$ \\
\hline B6 & Human dwelling & 5 \\
B11 & Human dwelling & 10 \\
R2 & Hospital & 3 \\
R3 & Hospital & 3 \\
H10 & Human dwelling & 3 \\
\hline Total & & 24 \\
\hline
\end{tabular}

None of collected samples from Sari were positive for C. neoformans growth.

\section{DISCUSSION}

In the present study, $5.2 \%$ of collected samples from swallow excreta were positive for $C$. neoformans. Although pigeon droppings have been documented as the major source of $C$. neoformans in nature, the presence of this yeast in many bird species other than pigeons, i.e., dove, psitaccines, budgerigars, canaries, parrots, cockatoos and starlings had also been reported ${ }^{2,7,13,20,21,25}$. In previous studies from Iran, $C$. neoformans was also isolated in $17.8 \%^{10}$ and $34 \%{ }^{28}$ of pigeon droppings. However, there are two reports of the isolation of Cryptococcus from captive passerine excreta ${ }^{6,17}$ but the current report appears to be the first describing the isolation of $C$. neoformans from Hirundo rustica excreta.

In this present study, all identified strains were found to be $C$. neoformans, no C. gattii was found in this study. Our observation is consistent with the findings of previous investigations that reported the predominance of $C$. neoformans in avian excreta ${ }^{14,15,19,22}$.

\section{CONCLUSION}

The results of this study demonstrate that excreta of swallows may harbor different species of potentially pathogenic yeasts (mainly $C$. neoformans and Candida spp.) and may be capable of disseminating these fungi in the environment. Furthermore, presence of the swallow, which houses in close proximity to human dwellings as well as around the special places such as hospitals, makes these birds a focus of interest for possible carriers and spreaders of pathogenic fungi. Swallows dwelling around hospitals is particularly interesting because of immunocompromised patients that are considered high risk for contracting opportunistic diseases. Therefore, our findings emphasize the potential importance of swallows in the contamination of the public and domestic environments and reinforce that bird excreta is a dangerous reservoir and potential source of inhaled $C$. neoformans.

Considering the incidence of human cryptococcosis in Iran and the fact that swallows are common in this country and in peaceful coexistence with humans in Iran, our results also emphasize the need for further study on the distribution of C. neoformans in swallow excreta from other regions of Iran as well as throughout the world.

\section{RESUMO}

\section{Isolamento de Cryptococcus neoformans de excrementos de andorinhas (Hirundo rustica) do Irã}

Cryptococcus neoformans é levedura encapsulada que pode causar criptococose, infecção potencialmente mortal que ocorre principalmente em pacientes imunocomprometidos. As principais fontes ambientais de $C$. neoformans são o solo contaminado com fezes de aves. No presente estudo, avaliamos o isolamento de $C$. neoformans de excreta de andorinhas (Hirundo rustica) em duas cidades do norte do Irã. Noventa e sete amostras de fezes de andorinhas foram avaliadas e 498 colonias semelhantes à levedura foram isoladas e identificadas como Rhodotorula spp. (62,8\%), Candida spp. (28,5\%), C. neoformans $(8,7 \%)$. Cryptococcus neoformans foi isolado a partir de 5/97 (5,2\%) das amostras coletadas. Unidades Min-Max formadoras de colonias (CFU) por 1 grama das amostras positivas foram 3-10 colonias de $C$. neoformans. A média total de CFU por 1 grama das amostras positivas foi de 4,8 . Os resultados deste estudo demonstram que excrementos de andorinhas podem abrigar diferentes espécies de leveduras potencialmente patógenas, principalmente $C$. neoformans, e podem ser capazes de disseminar estes fungos no meio ambiente. 


\section{ACKNOWLEDGMENT}

This study was financially funded by a grant from Mazandaran University of Medical Science, Sari-Iran, which we gratefully acknowledge.

\section{REFERENCES}

1. Bidjani Kh, Abbasi A. Pulmonary infection due to Cryptococcus neoformans in a patient without immunodeficiency: a case report. J Babol Univ Med Sci. 1999;1:54-6.

2. Criseo G, Bolignano MS, De Leo F, Staib F. Evidence of canary droppings as an important reservoir of Cryptococcus neoformans. Zentralbl Bakteriol. 1995;282:244-54.

3. Davis JA, Horn DL, Marr KA, Fishman JA. Central nervous system involvement in cryptococcal infection in individuals after solid organ transplantation or with AIDS. Transpl Infect Dis. 2009;11:432-7.

4. Ellis DH, Pfeiffer TJ. Natural habitat of Cryptococcus neoformans var. gattii. J Clin Microbiol. 1990;28:1642-4.

5. Franzot SP, Salkin IF, Casadevall A. Cryptococcus neoformans var. grubii: separate varietal status for Cryptococcus neoformans serotype A isolates. J Clin Microbiol. 1999;37:838-40

6. González-Hein G, González-Hein J, Díaz Jarabrán MC. Isolation of Cryptococcus neoformans in dry droppings of captive birds in Santiago, Chile. J Avian Med Surg. 2010;24:227-36

7. Granados DP, Castañeda E. Isolation and characterization of Cryptococcus neoformans varieties recovered from natural sources in Bogota, Colombia, and study of ecological conditions in the area. Microb Ecol. 2005;49:282-90.

8. http://en.wikipedia.org/wiki/Swallow

9. Jarvis JN, Harrison TS. HIV-associated cryptococcal meningitis. AIDS. 2007;18:2119-29.

10. Khosravi AR. Isolation of Cryptococcus neoformans from pigeon (Columbia livia) droppings in northern Iran. Mycopathologia. 1997;139:93-5.

11. Kidd SE, Chow Y, Mak S, Bach PJ, Chen H, Hingston AO, et al. Characterization of environmental sources of the human and animal pathogen Cryptococcus gattii in British Columbia, Canada, and the Pacific Northwest of the United States. Appl Environ Microbiol. 2007;73:1433-43.

12. Krockenberger MB, Canfield PJ, Malik R. Cryptococcus neoformans in the koala (Phascolarctos cinereus): colonization by $C$. neoformans var. gattii and investigation of environmental sources. Med Mycol. 2002;40:263-72.

13. Kumlin U, Olsen B, Granlund M, Elmqvist LG. Tärnvik A. Cryptococcosis and starling nests. Lancet. 1998;351:1181.

14. Kuroki M, Phichaichumpon C, Yasuoka A, Chiranairadul P, Chosa T, Sirinirund P, et al. Environmental isolation of Cryptococcus neoformans from an endemic region of HIV-associated cryptococcosis in Thailand. Yeast. 2004;21:809-12.
15. Kwon-Chung KJ, Bennett JE. Cryptococcosis. In: Kwon-Chung KJ, Bennett JE, editors. Medical Mycology. Philadelphia: Lea \& Febiger; 1992. p. 397-446.

16. Li SS, Mody CH. Cryptococcus. Proc Am Thorac Soc. 2010;7:186-96.

17. Lugarini C, Goebel CS, Condas LA, Muro MD, de Farias MR, Ferreira FM, et al. Cryptococcus neoformans isolated from passerine and psittacine bird excreta in the state of Paraná, Brazil. Mycopathologia. 2008;166(2):61-9.

18. Moghadami M, Kordbacheh P, Emami M. A case report of Cryptococcal meningitis. Iran J Publ Health. 1988;17:61-8.

19. Nielsen K, De Obaldia AL, Heitman J. Cryptococcus neoformans mates on pigeon guano: implications for realized ecological niche and globalization. Eukaryot Cell. 2007;6:949-59.

20. Nosanchuk JD, Shoham S, Fries BC, Shapiro DS, Levitz SM, Casadevall A. Evidence of zoonotic transmission of Cryptococcus neoformans from a pet cockatoo to an immunocompromised patient. Ann Intern Med. 2000;132:205-8.

21. Passoni LFC, Wanke B, Nishikawa MM, Lazéra MS. Cryptococcus neoformans isolated from human dwellings in Rio de Janeiro, Brazil: an analysis of the domestic environment of AIDS patients with and without cryptococcosis. Med Mycol. 1998;36:305-11.

22. Pedroso RS, Ferreira JC, Candido RC. The isolation and characterization of virulence factors of Cryptococcus spp. from saprophytic sources in the city of Ribeirão Preto, São Paulo, Brazil. Microbiol Res. 2009;164:221-7.

23. Rahbari Manesh AA, Tabatabaei P, Zamani A, Ghoreishi AS, Daneshjoo Kh. Systemic fungal diseases in children. Iran J Pediatr. 2005;15:271-5.

24. Segal E, Baum GL. Epidemiology, pathogenesis, immunopathogenesis and clinical manifestations of cryptococcosis. In: Baum GL, Segal E, editors. Pathogenic yeasts and yeast infections. Boca Raton: CRC Press; 1994. p. 205-17.

25. Sriburee P, Khayhan S, Khamwan C, Panjaisee S. Tharavichitkul P. Serotype and PCRfingerprints of clinical and environmental isolates of Cryptococcus neoformans in Chiang Mai, Thailand. Mycopathologia. 2004;158:25-31.

26. Vilcins I, Krockenberger M, Agus H, Carter D. Environmental sampling for Cryptococcus neoformans var. gattii from the Blue Mountains National Park, Sydney, Australia Med Mycol. 2002; 40:53-60.

27. Zaini F, Safara M, Kordbacheh P, Pezeshki M, Beheshti B. Anti-cryptococcal-globulinlatex production for rapid detection of Cryptococcus neoformans polysaccharide antigen in cryptococcosis. Iran J Publ Health 2005;34(4):15-23.

28. Zarrin M, Jorfi M, Amirrajab N, Rostami M. Isolation of Cryptococcus neoformans from pigeon droppings in Ahwaz, Iran. Turk J Med Sci. 2010;40:313-6.

Received: 3 January 2011

Accepted: 19 April 201 


\section{Revista do Instituto de Medicina Tropical de São Paulo on line.}

Publications from 1990 to the present data are now available on:

http://www.scielo.br/rimtsp

PAST ISSUES 1959-1989 (PDF)

www.imt.usp.br/portal/

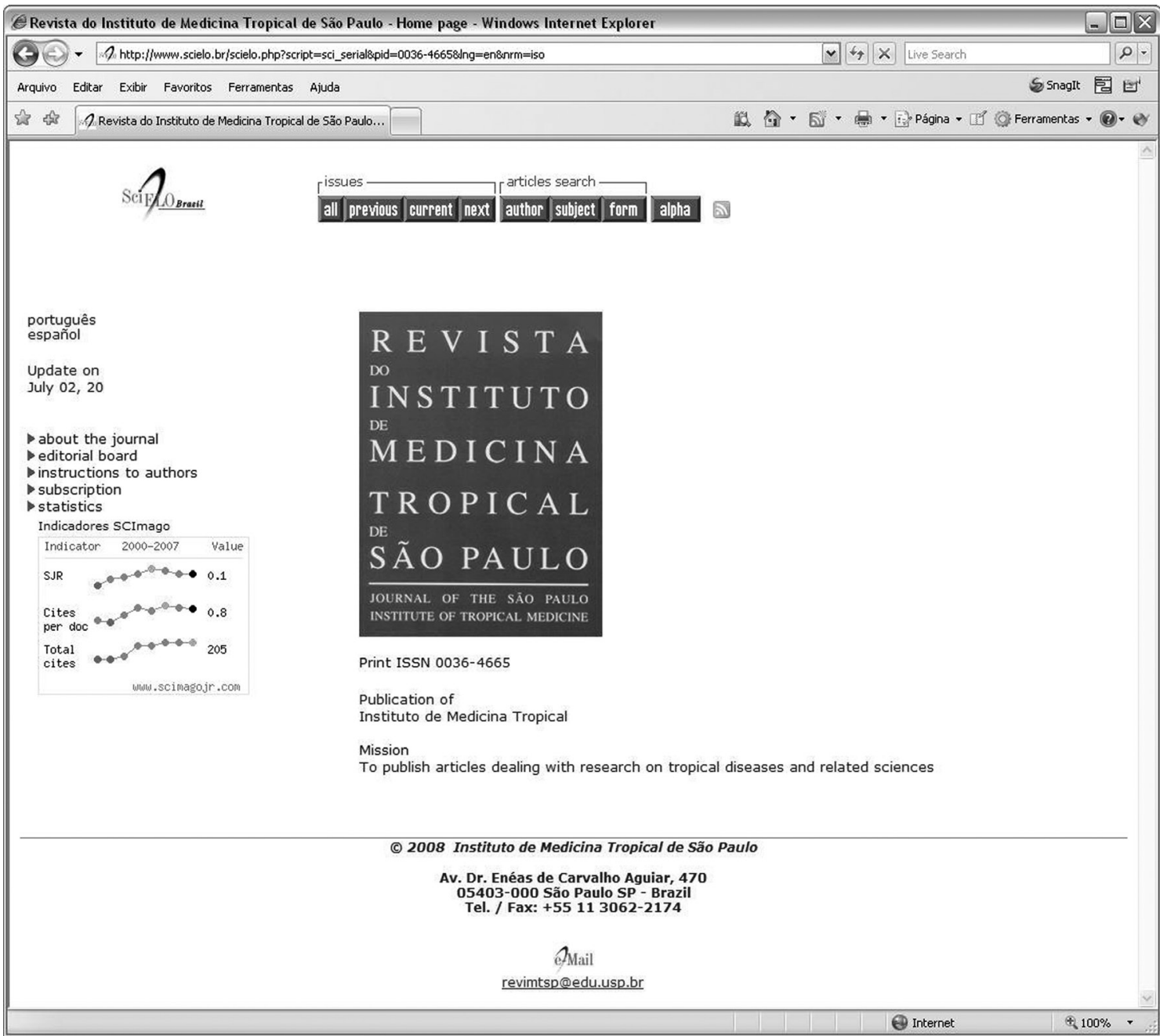

SciELO - The Scientific Electronic Library OnLine - SciELO is an electronic virtual covering a selected collection of Brazilian scientific journals.

The library is an integral part of a project being developed by FAPESP - Fundação de Amparo à Pesquisa do Estado de São Paulo, in partnership with BIREME - the Latin American and Caribbean Center on Health Sciences Information.

SciELO interface provides access to its serials collection via an alphabetic list of titles or a subject index or a search by word of serial titles, publisher names, city of publication and subject.

The interface also provides access to the full text of articles via author index or subject index or a search form on article elements such as author names, words from title, subject and words from full text.

FAPESP/BIREME Project on Scientific Electronic Publications Latin American and Caribbean Center on Health Sciences Information

Rua Botucatu 862 - 04023-901 São Paulo, SP - Brazil

Tel. (011) 5576-9863

scielo@bireme.br 